\title{
Aspects of regulatory reform in the legal profession: Australia, Ireland and the Netherlands
}

\author{
Edward SHINNiCK*, Fred Bruinsma† \& \\ CHRISTINE PARKER $\ddagger$ \\ *Department of Economics, University College Cork, Western Road, Cork, Ireland \\ †Department of Legal Theory, Law Faculty, Utrecht University, the Netherlands \\ $\ddagger$ Law Faculty, University of Melbourne, VIC 3010, Australia
}

\section{Introduction}

Regulation has transformed the role of government and business through establishing a series of rules and guidelines that aim to promote efficiency and economic growth while at the same time protecting consumer interests. Several economic activities are subject to regulation, ranging from air transport, to telecommunications and retailing. Suppliers of professional services are, however, subject to possibly the greatest amount of regulation, such as rules on advertising behaviour, fee calculation and general conduct in the provision of such services. The reasons for such extensive involvement centre on market failure, principally an information asymmetry between providers and clients. This asymmetry is used to restrict the provision of professional services on claims of protecting clients against incompetent practitioners, because clients have less information than suppliers and so cannot judge the quality of the service themselves. This asymmetric information problem is compounded by the infrequency of purchase. The solution up to recently has been regulation. ${ }^{1}$

This paper surveys and analyses aspects of the national programmes of regulatory reform in the Australian, Irish and Dutch legal professions, starting with the current extent of reforms that are mostly economic based. The coverage between the three countries is not necessarily equal due to differences in the extent of the regulatory reform process and differences in the amount of empirical evidence in each of the three countries. We focus on competition reforms because in each of the three countries studied, this type of reform is at the forefront of the regulatory reform agenda. From this economic focus we detail what issues have not been fully addressed in the regulatory reform agenda and how this can be overcome by augmenting the traditional economic approach with a sociological approach to

Address for correspondence: Edward Shinnick, Department of Economics, University College Cork, Western Road, Cork, Ireland. E-mail: e.shinnick@ucc.ie 
regulatory reform, through a mix of self-regulation, state regulation and marketbased incentives. ${ }^{2}$

The structure of the paper is as follows. After this introduction, the theoretical context for regulatory reform in the legal profession is outlined. This is followed in §III by an outline of the regulatory reform programmes in Australia, Ireland and the Netherlands. \IV makes a comparative evaluation of regulatory reform in the legal profession across the three countries. $\ \mathrm{~V}$ concludes with a discussion of the issues.

\section{Regulatory reform and the legal profession-the theoretical context}

In theory, a free market in professional services will have two undesired consequences: (i) adverse selection, i.e. the quality of the professional services will deteriorate, because bad and cheap quality drives out good and expensive quality; and (ii) moral hazard, i.e. the professional has no external incentives to deliver good quality due to the minimal risk of detection by the client. In practice three partial solutions can be distinguished, namely market-based incentives (such as advertising), self-regulation and state regulation. Each has its own adverse side effects. As regards to advertising, Stigler (1961) argued that it may reduce the information problem, if advertising can reduce search costs for consumers and inform them of price differences. As a consequence large price dispersions become less likely. Advertising is therefore a crucial source of information necessary to achieve competitive behaviour in professional services. Advertising is not the panacea, however. It might redress the information asymmetry for repeat corporate customers, but it is less helpful to private customers who rarely use legal services, i.e. Galanter's (1975) one shot players.

Too much reliance on self-regulation is also ill advised, because it easily conflicts with self interest. The self-regulatory regime inherent in many professions focuses on the behaviour of suppliers in the conduct of their profession and it consequently affects how the market for such services functions. Characteristics of self-regulation have the potential to act like those of a cartel. For example, the powers of professional associations may lead to: (i) entry controls; and (ii) setting agreed prices above the competitive level so that members of the profession earn economic rents.

State regulation can also fail when it does not achieve its desired initial objective(s). It can end up impeding growth, innovation, price competition, entry, investment and efficiency. As a consequence social goals, such as access to justice, can also be impeded. The regulatory system can become overly bureaucratic especially when the economy has experienced rapid growth. In addition regulation does not always achieve the goals it was set up to achieve, through for example, the influence of vested interests seeking to block competition. When these occur we have what is termed regulatory failure and this is the primary reason why governments may pursue a policy of regulatory reform.

Regulatory reform: what is it, why is it needed and how does it work?

As a key concept we use regulatory reform instead of the term deregulation because what has occurred in the legal profession can best be described as re-regulation or 
regulatory reform. Regulatory reform is a wide-ranging concept and includes issues in competition and quality of service. Examples of these issues include: admission, education, specialisation, certification, public protection, standard setting, complaint procedures and access. These issues often overlap; for example, education and admission have implications for competition through the number of students allowed into a programme and it also has implications for quality of service that is dependant on the quality of education.

The most conspicuous restrictive practices such as prohibitions on advertising and on price competition have largely been abolished. Self-regulating legal professional associations no longer have such unaccountable power over regulatory arrangements for their profession. At the same time new principles of competition and consumer quality have been introduced to the regulatory reform process. Yet more needs to be achieved to further enhance competition in professional services and simultaneously address the asymmetric information problem. To achieve this, regulatory reform policies must consist of an optimal mix of state regulation, selfregulation and market incentives.

The benefits of regulatory reform can be wide ranging, bringing advantages to existing firms in the industry, firms seeking entry into the industry and to consumers alike. In the process the country becomes more competitive, tax revenues increase and the public budget is healthier. The OECD (1997) estimated the benefit of regulatory reform across several countries. In Japan, efficiency gains from reforms resulted in an increase in consumer income by $0.3 \%$ per year, or $\$ 36$ billion. In the United States, reforms in a wide range of sectors resulted in benefits to consumers and producers of $\$ 42$ billion to $\$ 54$ billion. In general, successive OECD country studies indicate that regulatory reforms across many different sectors in the economy can increase GDP growth by up to $0.5 \%$ per annum. For Ireland, Fingleton (1997) estimates that monopoly profits may amount to hundreds of millions of euros in individual markets, costing the economy several percentage points of GDP. Such losses can be attributed to high structural concentration, regulatory barriers to entry and anti-competitive behaviour across a wide range of markets. Indeed in Ireland a culture of cooperation as against a culture of competition can be said to exist. The same holds true for the Dutch economy that has been called a 'poldermodel' because of the regular consultations between interest groups and the informal veto power each affected interest has. ${ }^{3}$ Van Hulst (1996) calculated monopoly rents to notaries of $€ 163$ million annually, to pharmacists of $€ 136$ million and to estate brokers of $€ 113$ million in the Netherlands.

The benefits of regulatory reform are therefore large and, once implemented, these reforms can continue to provide benefits. A programme of regulatory reform has market structure as its main focus (see, for example, Stigler, 1968; Ogus, 1994). In particular, a market with few firms is perceived to be inefficient when compared to a perfectly competitive market and this leads to welfare $\operatorname{losses}^{4}$ of three kinds (Van Hulst, 1996). A first welfare loss can be attributed to market dominance resulting in price setting above the competitive level. A second welfare loss is attributed to inefficiencies arising from the misallocation of resources (allocative efficiency), from pricing above cost (productive efficiency) and from a lack of 
innovation (dynamic efficiency). Expenses associated with rent seeking (e.g. advertising, sponsoring and lobbying) are a third type of welfare loss.

Another concern is the interaction between producers and consumers. This can include the degree to which production is controlled by a few firms, the degree of product differentiation, the extent of entry barriers and the maintenance of quality and standards. The idea here is by liberalising entry conditions, entry and even the threat of entry is sufficient to force incumbent producers to be efficient and provide a service that consumers value. However the perceived benefits of the market system do not always materialise due to market failure, brought about by, for example, monopoly power or imperfect information. Reducing both welfare losses and market failures forms the rationale behind government intervention.

\section{Beyond current regulatory reform}

While the economic theory behind regulatory reform seeks to cure welfare losses and market failure, sociology sees the problem as somewhat broader. Larson (1977), for example, identifies two aspects of professions: (i) claims of special knowledge and skills to strive for market control (economic power) through monopolisation; and (ii) social status (social power) through a collective mobility project. Selfregulation is aimed at ensuring minimal competition between members so that the profession acts in solidarity to advance the collective goals of monopoly and status. Professional power and prestige become ingrained in the culture of doing things because the profession defines the way knowledge in their area of expertise is produced and defined. Abel $(1988,1989)$ was the leading advocate of this approach to the legal profession in the US, England and Wales, while O'Malley (1983) and Weisbrot (1990) applied the same approach to their empirical work on the Australian legal profession. Critiques of the legal profession provide a social institutional analysis of the legal profession's relations with society. Larson (1977), for example, attempts to demystify legal professional ideology by exposing the 'business' of practising law for what it is in terms of market, social prestige and ideological control.

When it comes to proposing alternatives to the status quo, reformers tend to focus on economic market controls. Although a pure competition analysis is useful it cannot clearly state the extent of the problem, nor prescribe a complete solution. If Larson and later theorists are correct, then legal professional deregulation might affect not merely the achievement of monopoly rents, but public and legal professional conceptions of lawyers' autonomy and superiority in defining, shaping and interpreting the law in its application to clients. It is social institutions along with a successful ideological war waged in culture, individual workplaces and in markets that accomplishes professional jurisdiction (Abbott, 1988).

Therefore, the sociology of knowledge and its explanations of how professionals control the way knowledge is constructed in the fields they dominate is also necessary. Abbott (1988), Dezalay and Garth (1996) and Shamir (1995) each show how professional jurisdiction and domination of an area is accomplished on the basis of real social situations, micro-institutions and the regulatory schemes set out 
in legislation. In particular, Abbott (1988) sees professions primarily as competitors for contestable jurisdictions, which conceptual knowledge is developed to deal with. The extent of each profession's jurisdiction will depend on the success of its own claims to knowledge and expertise in relation to the claims of contiguous occupations. Shamir (1995) identifies legal knowledge and lawyers' work as inseparably linked through the interaction of ideas and not just a contest for economic self-interest. It is a struggle between occupations and segments of occupations for the right to define legal knowledge, especially the symbolic meaning of law's autonomy, in which ideas are as important as economics. Dezalay and Garth's (1996) analysis of US lawyers' triumph over the field of global commercial arbitration (also inspired by Bourdieu) takes a similar approach.

It is clear, therefore, that in the sociology of professionalism ${ }^{5}$ the lawyer's monopoly is more than a matter of economics. It extends far into the way people experience justice and the legal system. That is why, as Halliday (1987) showed, a legal professional association can attain a level of cultural acceptance and stability where it is no longer important for it to maintain the formal features of its monopoly. It socialises the legal apprentices into fully-fledged lawyers who perpetuate standard definitions. At this point legal professionalism has become institutionalised in the way people think about law and justice. It is in this context that economic oriented competition reforms alone may not be enough to budge the socially entrenched 'jurisdiction' of the legal profession. As Halliday (1987) and Dietrich and Roberts (1997) maintain, the formal conditions of monopoly may be removed, but the social domination of legal professionalism will remain. Thus it is not possible to simply renegotiate the social bargain between the legal profession and the state to require more competition and more accountability than before, while allowing the profession to retain its basic privileges [see, for example, Paterson $(1995,1996)$ and Dingwall and Fenn (1987) for an extension of this argument].

In recent times, regulatory reform has attempted to diminish the power of the professions. ${ }^{6}$ However large amounts of power still remain, such as the growth of professional power in lobbying against regulatory reform that affects the group's interests (see, for example, Kagan, 1996). The public choice theory attempts to explain policy outcomes by referring to the strategic behaviour of lobbyists in the legislative arena (Olson, 1965). Wilson (1980) predicts different regulatory outcomes depending on the extent of concentration of costs and benefits. The most biased outcome takes place if the benefits go to a small group and the costs are diffused. In such circumstances one may expect regulation will serve the interests of the small group. As we see below, Ireland offers a striking example.

\section{Regulatory reform programmes in Australia, Ireland, and the Netherlands}

Australia

Introduction -impetus for reform. Traditionally, professional associations of barristers and solicitors under enabling state legislation governed the structure, organisation 
and regulation of legal practice in Australia. ${ }^{7}$ At the pinnacle of self-regulation, the law societies disseminated and enforced standards of professional conduct, investigated and prosecuted complaints and provided the disciplinary tribunals to hear charges. They also decided on qualifications for admission, issued practising certificates, policed compliance with trust account rules and administered fidelity funds and insurance schemes (Disney et al., 1986). Self-regulation and its supporting legislation and court rules set entry conditions for the profession, entrenched lawyers' monopolies on legal work, set standard fees and prohibited most forms of competition between lawyers including any form of advertising or price competition. The Bar Associations issued their own rules requiring any lawyer who wished to practise advocacy before the higher courts to restrict themselves to practise as a barrister only, to accept clients only through a solicitor, not to form a partnership with other lawyers and to practise from approved chambers.

Throughout the 1970s and 1980s a litany of law reform commission reports, government inquiries, social and political campaigns and scholarly articles criticised the legal profession for high prices, lack of interest in providing high quality service to consumers, lack of commitment to access to justice for the poor, failures of complaints and disciplinary systems to deal with consumer complaints of delay, unfair billing practices and negligence, lack of openness to women and Aborigines and an excessively adversarial approach to dispute resolution (see Disney et al., 1986; Parker, 1997a, 1997b; Weisbrot, 1990). In the late 1980s Australia's federal competition regulator (the Trade Practices Commission, later renamed the Australian Competition and Consumer Commission) began to review the legal profession and the federal government set up a broad-ranging national competition reform process in cooperation with the states. Significant regulatory reform to state legal professions was prompted by the threat of federal competition reform. The concerns of the 1970s and 1980s were included in a politically effective campaign for competition reform. This reform continues under the aegis of the National Competition Council which holds state governments accountable for reviewing all areas of regulation in line with national competition principles.

Overview of reforms. The history of reform in New South Wales (NSW) illustrates how significant reform was achieved mostly with the impetus of the competition policy agenda and rarely when concerns were confined to access to justice and consumer service. The NSW Law Reform Commission began an inquiry into legal professional regulation in 1976 and lasted until 1984 (Disney et al., 1986; Weisbrot, 1990). By 1980, the Commission had concluded that NSW lawyers had been immune to the consumer rights revolution and systematically failed to operate in a way oriented to the needs and concerns of their clients. The structure and organisation of the profession institutionalised restrictive practices that made legal services unduly expensive. Such practices included requirements that: (i) clients could only hire a barrister by hiring a solicitor first; (ii) if they hired a Queens Counsel (QC) they must also hire a junior barrister at two thirds the QCs fee; (iii) lawyers were prohibited from advertising their fees or services; (iv) qualified conveyancers could not compete with lawyers; and (v) solicitors' costs were governed by a scale of fees 
and it was prohibited to charge less than the scale fee. Individual lawyers were often unhelpful to clients and showed insensitivity to client needs, particularly in explaining their billing practices. In addition, the profession's regulatory structure failed to address the issues that most frequently concerned clients, such as, delays, negligence, poor communication and problems with charging (NSW Law Reform Commission, 1980, 1982; see also Weisbrot, 1990).

The Law Reform Commission initially proposed radical changes such as abolishing all restrictive practices, fusing the profession, and taking away all selfregulatory functions and vesting them in an independent body that would be only partially composed of lawyers (NSW Law Reform Commission, 1979). These early proposals met strong resistance from the profession and government support also faded with a change of Attorney Generals. In 1982 the Commission's final recommendations were much less radical. They recommended that regulatory and complaint handling for the profession remain self-regulatory but with the involvement of lay representatives and the process should be more streamlined. Practitioners should be admitted to both branches of the profession and distinctions between barristers and solicitors be eliminated to the extent possible. In addition, the Bar Council should ease restrictive practices at the Bar (Weisbrot, 1990). The recommended reforms were to be implemented (with Law Society support) in 1984 when the Attorney General, Paul Landa died (Ross, 1995) and as a result the reforms faded from government priority until a new state government enacted the Legal Profession Act 1987. This Act implemented the lay representation recommendations and the new complaints and disciplinary process but not the more farreaching recommendations concerning fusion of the profession and abolition of restrictive practices.

In 1991 the Law Society of New South Wales could no longer withstand pressure and relaxed its prohibition on advertising, allowing advertising as long as it could not "reasonably be expected to bring the profession into disrepute". ${ }^{8}$ In 1992 the state government removed the solicitors monopoly on conveyancing by allowing licensed lay conveyancers. ${ }^{9}$ What followed over the next few years was a series of reports on the legal profession that proposed further change. In 1993 the Hilmer Report (Hilmer et al., 1993) identified the professions, especially lawyers, as representing a significant gap in the implementation of economic reform. Both the Trade Practices Commission (TPC, 1992, 1994) reviews and the Hilmer Report highlighted the need for regulatory reform of legal professions primarily for business consumers of legal services. The restrictive practices of the profession were now seen as not just an obstacle to consumer access to justice, but also to the national and international competitiveness of Australian business.

In 1993 the NSW Law Reform Commission again studied the profession at the request of the Attorney General (Weisbrot, 1993). It developed a set of best practice principles for complaint handling and repeated their earlier review of client complaints and how they were handled (NSW Law Reform Commission, 1993). ${ }^{10}$ The 1993 Legal Profession Reform Act (NSW) applied competition principles to the NSW legal profession and abolished a number of restrictive practices by: (i) allowing multi-disciplinary practices subject to certain restrictions; (ii) allowing clients direct 
access to barristers subject to restrictions; (iii) no longer letting the Crown appoint QCs; (iv) allowing common admission to the profession for barristers and solicitors and common practising certificates; (v) abolishing two thirds rule; (vi) allowing solicitors to act as advocates and as juniors for senior counsel; (vii) allowing conditional fee contracts; ${ }^{11}$ (viii) lifting restrictions on advertising; (ix) abolishing scale fees and introducing rules requiring upfront disclosure of fees by lawyers; ( $\mathrm{x}$ ) encouraging costs agreements; (xi) simplifying procedures for handling client fee complaints; and (xii) allowing licensed conveyancers to compete for conveyancing. ${ }^{12}$

The traditional self-regulatory complaints and disciplinary process was also reformed. The Office of the Legal Services Commissioner (OLSC) now receives all complaints and resolves many consumer type complaints informally. Most of the complaints that are not easily resolved are still referred to the (self-regulating) Law Society and Bar Association Councils for investigation and prosecution. The codes of professional conduct and practice also remain self-regulatory.

New South Wales was not the only state to respond proactively to the TPC and Hilmer reports. The threat of federal reform and regulation of state professions, through granting the TPC regulatory powers, prompted a number of state governments to announce their own reviews of the profession. For example, in Victoria, law reform discussions in the late 1980s and early 1990s resulted in reforms (e.g. Law Reform Commission of Victoria, 1991, 1992a, 1992b). In the mid-1990s a very vocal consumer lobby group were able to persuade the reformist Attorney General to reform the legal profession. The state government introduced comprehensive reform only when the federal competition policy agenda was in full flight and such reform was undoubtedly enhanced by a perceived mismanagement of the Law Society's fidelity fund. ${ }^{13}$

In 1993 the Victorian Bar Association, which had been targeted by both the TPC and state government reformers as the most restrictive of Australia's legal professional associations, gave in to pressure by proposing a consolidated revision of its rules to reduce restrictive practices. Further amendments were made in 1994 with new provisions relating to chambers, direct access, co-advocacy and advertising. In 1994 the Victorian Attorney General issued a paper calling for radical change and appointed a working group to make recommendations on the proposed changes (Wade, 1994; Craven, 1995). The result was the Legal Practice Act (Vic) 1996 which abolished various restrictive practices and also the presumption that the Law Institute (the solicitors' association in which membership was compulsory) and Bar Association were competent self-regulators. Lawyers must now be members of a 'recognised professional association' (RPA), which will license and regulate them and handle complaints and disciplinary proceedings under the oversight of an independent ombudsman. Any professional association can apply to the Attorney General to become a RPA and approval must be regularly renewed. ${ }^{14}$ Currently however the traditional self-regulators, the Bar Association and Law Institute, are the only RPAs.

The 1996 reforms to the Victorian legal profession were successful from a competition policy perspective by abolishing a number of restrictive practices. However, they have been less successful at providing consumers with a single, 
speedy, fair, transparent and independent procedure for handling complaints (Cerexhe, 2001). Nor have these reforms addressed fundamental problems with the profession's conduct rules and the process for investigating and prosecuting complaints against lawyers which reflect a narrow conception of proper professional conduct and do not reflect community expectations about lawyers' roles in promoting justice (see Parker, 2002). The 1996 reforms were inherently unstable and the early 2000s saw further pressure for reform from both the profession, which is unhappy with its decreased role in re-regulation, and the Legal Ombudsman, who is an active critic of the profession's use of its continuing self-regulatory powers (Merritt, 2001a; Towers, 2000, 2001). A government paper proposing further reforms to the regulation of the Victorian legal profession was issued in November 2001 (Sallman \& Wright, 2001) and in late 2003 the Attorney General announced that a model similar to that in New South Wales would be introduced in 2004. Critics, including the current Legal Ombudsman, are unhappy with this reform since in practice it is likely to rely heavily on self-regulation to investigate and prosecute complaints (as in New South Wales). The new Legal Services Commissioner will also report to a board that will not be sufficiently independent of the profession (see Silverii 2003).

In the smaller states the history of bodies recommending reforms during the 1970s and 1980s was generally not as strong as in NSW and Victoria. However, in Western Australia (alone of all the states) comprehensive reforms had occurred in the early 1980s. This resulted in a regulatory structure in which the barrister and solicitor professions were fused and legal professional associations exercised no selfregulating functions. An independent Legal Practice Board together with a statutory Complaints Committee and Disciplinary Tribunal exercised all regulatory functions over the legal profession (Weisbrot, 1990). In the Australian Capital Territory the federal Trade Practices Act applied to the legal profession since 1975, due to peculiarities of Australian federalism, so that the restrictions on advertising and lay conveyancing that existed in other states had never taken root there.

In the other states sporadic reforms to make the professions more transparent and accountable had been attempted in the 1970s, 1980s and early 1990s but had little effect and none had been as comprehensive and critical as in NSW. Nevertheless when the TPC began to look at the state legal professions, state governments acted. In both Queensland and South Australia, for example, the state government introduced reforms aimed at similar issues and modelled to some extent on reforms mooted in New South Wales (e.g. Government of S.A., 1992). In some of the states (South Australia, Tasmania and Australian Capital Territory) lay conveyancers were never restricted from competing with solicitors. In all the states this reform was mooted and restrictions on advertising, on practising as both an advocate and a solicitor and practising in different states at the same time were lifted. In Queensland however, the Premier took pity on solicitors and did not allow lay conveyancing as threatened, but rather promised to introduce lay conveyancers if prices did not drop within two years. ${ }^{15}$

By 1996 a cooperative scheme of federal and state legislation applied the competition principles of the Trade Practices Act to all businesses throughout Australia (Corones, 1996; Fels, 1997) and committed state governments to ongoing review 
of all their legislation on competition principles including further reform in the legal profession. ${ }^{16}$ For example in 1998 the NSW government raised the real possibility of limited deregulation. ${ }^{17}$ It suggested a voluntary system of licensing in which competence is certified by professional associations, rather than the current system of admission as an officer of the Supreme Court of NSW and also suggested selective licensing in particular areas of practice, rather than licensing for all practitioners (Young, 1998). In 2000, the New South Wales government passed legislation allowing for the incorporation of large law firms under normal company law and limited liability for partners (Shaw, 1999). ${ }^{18}$

In most states, however, reforms motivated by competition policy have not been sufficient to prevent ongoing criticism of the regulation of legal professions. Nor has it prevented a number of recent scandals in which self-regulatory professional associations have failed to prevent significant misconduct or failed to handle misconduct adequately. For example, in New South Wales a number of high profile attempts to discipline lawyers have failed because the courts have found the legal professional association's investigation procedures lack procedural fairness. This has resulted in further recommendations for reform (NSW Law Reform Commission, 2000, 2001a, 2001b).

The NSW proposals appear to be gathering dust on the Attorney General's desk. However in 2002 the NSW Attorney General did announce further reforms to improve competition in the profession by making fee structures more transparent, permitting voluntary membership of the legal professional associations and opening up the profession to practitioners from other states (Marshall, 2002). In Queensland the solicitors' association has become mired in controversy over its failure to investigate complaints or to use the fidelity fund to compensate clients (Priest, 2001; Griffith, 2002). A scathing report by the legal ombudsman has recommended that the professional associations lose all regulatory roles (Legal Ombudsman, 2002, also known as the Shanahan Report). Legislation establishing an independent Legal Services Commissioner and Tribunal was passed in late 2003. But it appears that the independent regulator will still be able to refer matters to the self-regulating professional associations for investigation. Tasmania introduced similar reforms for similar reasons in 2003 (see Merritt, 2001b).

Summary. The impact of the competition policy agenda on the Australian legal profession has been somewhat paradoxical. On the one hand, the work of the TPC and the Hilmer Report started a reform process that would otherwise have remained just recommendations to which state governments had no particular political commitment. On the other hand, the political commitment to the competition reform process in the 1990s threatens to obliterate work by government reformers on other aspects of legal professional reform such as access to justice and consumer protection. This is not to say that no consumer protection or access to justice-oriented reforms have occurred. There has been some important reforms in these areas, but they have mostly occurred only under the impetus of, and been overshadowed by, competition reforms. ${ }^{19}$

There is now a danger that the ongoing impetus for regulatory reform of the 
legal profession will be the national competition agenda alone and that access to justice and consumer critiques of the legal profession will disappear from the debate. As the discussion above shows, there are many sensible non-competition reform proposals on the books that state governments have not been sufficiently motivated to implement. Meanwhile the State and Federal Attorney Generals are actively planning how to progress the economic reform agenda for nationalisation of the profession and implementing reforms (see Law Council of Australia, 2001; Merritt, 2002). The history of reform in Australia is becoming one of concern with access to justice being swallowed up by competition reform.

\section{Ireland}

Introduction -impetus for reform. Like their Australian counterparts the Irish legal profession is divided into solicitors and barristers. The solicitors' profession is governed by the Solicitors Act of 1954 and 1960 and is controlled by the Law Society. Barristers are governed by the rules of the Bar Council. The statutory functions of the Law Society include the maintenance of a roll of practising solicitors, the determination of educational requirements for entry to the profession and the regulation of solicitors' accounts, professional practice, conduct and discipline. The legislation prohibits multi-disciplinary practices, transnational practices and practising through the vehicle of a limited company. Solicitors may practise in association as partners. The self-regulatory regime of each profession along with the division of the profession into barristers and solicitors has the potential to give rise to restrictive practices within each profession and between the two professions, which may not be in the public interest. The distinction between the roles of solicitors and barristers has diminished, in theory at least, since 1971 when solicitors were allowed to represent their clients in all Irish courts. Prior to this, solicitors could only appear in the District and Circuit Courts, with barristers holding a monopoly position in all other courts. However solicitors have not taken up their rights to appear in the higher courts and barristers have not undertaken any traditional work associated with solicitors despite been allowed to do so.

One of the earliest reports on the solicitor profession was the Restrictive Practices Commission (RPC) Report 1982. This report set out to examine the nature and extent of competition among solicitors with particular reference to the conveyancing market. One of the issues raised in this report was the necessity of ensuring that the Law Society's control over entry to the profession was not used as a means of protecting the interests of those already in the profession. Furthermore the RPC noted that the solicitor's 'monopoly' on conveyancing constitutes a restriction, which can only be justified if it is shown to be necessary to preserve interests of even greater importance. The majority of the Commission were in favour of allowing a vendor to employ a non-solicitor as his conveyancer but not a purchaser and they recommended solicitors should be allowed to advertise their services but were in favour of retaining the ban on advertising fees (RPC, 1982).

The Fair Trade Commission (FTC) Report was a far more comprehensive study of the legal profession and lasted six years. In its report the FTC criticised the 
division between solicitors and barristers saying that it was "inefficient by involving unnecessary duplication, it lengthened the time taken to do business and with the large number of professionals involved it resulted in the payment of excessive fees" (FTC, 1990, p. 61). The division was considered not to serve any useful purpose because very often the solicitor, who had complete knowledge of the case, could handle the job more efficiently without having to explain the case to the barrister. The FTC Report also supported certain restrictions on the supply of conveyancing until the process of land transfer is simplified but was in favour of allowing banks and building societies to provide conveyancing. Freedom of entry to the profession was favoured, consistent with the maintenance of acceptable, but not excessive, standards, with the market for professional services being allowed to determine the number of practitioners. On legal education, the FTC stressed the need for a new appraisal of the entire system of legal education and was particularly concerned about the Law Society's control over the entrance examination.

The FTC came out strongly against advertising restrictions and noted that most people outside the profession were in favour of allowing solicitors to advertise, as it was thought this would encourage competition. Advertising was considered to only support ignorance in the market and any restrictions on advertising were a serious limitation to competition. The FTC did not accept that restrictions on advertising "either increase the quality of the service provided, helps to maintain standards, or lessens the confidence of consumers in the integrity of the profession" (FTC, 1990, p. 322). Moreover, the FTC maintained that if competition is allowed, it is likely that fees will be lower, resulting in greater efficiency without compromising the quality of the service. The Commission also came out strongly against mandatory fee scales and considered that recommended and maximum fees will tend to be considered as fixed charges. In particular, scale fees for conveyancing were seen as "a serious detriment to competition without any compensating advantages and therefore were unfair and contrary to the common good" (FTC, 1990, p. 318). They concluded that the Rules and Orders prescribing solicitors' fees for conveyancing should be revoked and that the Law Society should not issue any recommendations on fees to its members.

The extent of the drive for changes in the Irish legal profession, as put forward in both the RPC and the FTC, can be gauged by the submissions made to these committees. The RPC received 33 submissions, 26 of which were not directly linked to the legal profession but came from a broad range of business and consumer interests. The FTC acknowledged over 80 submissions but omitted the names of those who made submissions for confidentiality reasons. However, they did indicate "submissions came from the Law Society, Bar Council, teachers of law, industry practitioners, non-practicing barristers, various interest groups and members of the public" (FTC, 1990, p. 3).

Overview of reforms. The reports by the RPC and in particular the FTC prompted a new look at the regulation of the legal profession. However, most of the significant changes that have occurred in the profession are limited to advertising reforms. In fact over the past 10 years, the government has introduced five separate pieces of 
legislation dealing with solicitor advertising. The result has been significant changes, both positive and negative, in advertising restrictions.

Despite the publication of the RPC Report in 1982, legislative measures only began in 1988 with the Solicitors (Advertising) Regulations 1988. Prior to 1988 solicitors were forbidden to advertise their services or to do anything that may be regarded as touting for business. To do so, was considered by the Law Society as 'unprofessional' and would bring the profession into disrepute. With the introduction of the 1988 regulations solicitors were permitted to advertise their services in any media but were still forbidden from specifying a fee for any service. Solicitors are still prohibited from carrying out their practice in any way that may reasonably be regarded as touting or as attracting business unfairly. They can claim superiority for the quality of their practice over those of other persons, provided these other people are not solicitors.

A lot of the FTC recommendations were addressed in and indeed informed the Solicitors (Amendment) Bill 1994. Two of the most significant recommendations dealt with advertising controls and competition in conveyancing services. Section 69 of the 1994 Bill went further than the 1988 regulations and allowed solicitors to advertise their fees. This was a direct attempt to curb the asymmetric information problem inherent in professional services by providing consumers with information on fees. Section 79 of the 1994 Bill proposed to allow banks and insurance companies to provide conveyancing services, thus providing competition in this market. In a major u-turn, the government dropped Section 79 before the Bill was enacted in November 1994, while the Law Society supported most of the other sections (see text below at Irish Regulatory Reform Captured).

The Solicitors (Amendment) Bill 1994 contained over 80 sections. Some of the more substantial changes to the regulations were: (i) increase powers of the Law Society and the High Court to intervene in solicitors' practices in the interests of clients; (ii) give clients a right of redress where a solicitor provides inadequate services or where charges for services are thought to be excessive; (iii) allow for the appointment of up to five lay members to the Disciplinary Committee of the High Court; (iv) introduce tougher financial penalties and criminal offences for breach of client funds; (v) require the Law Society to publish information annually on complaints and the outcome of investigations; (vi) introduce requirements that solicitors are fully insured against damages awarded to clients arising from negligence; (vii) reduce the period of apprenticeship from a maximum of five years to a maximum of two years; (viii) reduce from seven to five years the minimum period of continuous practice required before a solicitor can take on an apprentice; (ix) permit solicitors two apprentices instead of one and an apprentice for every two assistants; and (x) require solicitors to provide, at the outset, particulars in writing of actual charges or an estimate of charges.

The next three pieces of legislation sought once again to place restrictions on solicitor advertising. The Solicitor (Advertising) Regulations 1996 were introduced to curb misleading advertising. Such advertising centred around the 'no win no fee' claim made by some solicitors which state that clients would only have to pay fees if they won their civil actions for damages. The employers' organisation IBEC and 
the insurance industry maintained that these claims made by solicitors contribute to a 'compensation culture'. The 1996 legislation stipulated that solicitors now have to advise their clients that they could be liable for costs and expenses awarded against them by the courts if they lose their case.

The Solicitors (Amendment) Act 2002 outlined a general objective of restricting advertising for personal injury cases. The Solicitor (Advertising) Regulations 2002 (see below) gives specific details of these restrictions. The 2002 Act also contains nonadvertising measures such as: (i) strengthening the powers of the High Court to prohibit an activity it considers to be in breach of the regulations; (ii) new powers for the Law Society to inspect a solicitor's accounts and bank statements; and (iii) changes in the composition of the Solicitors Disciplinary Tribunal to include a maximum of 20 solicitors and a maximum of 10 'lay members'.

The Solicitor (Advertising) Regulations 2002 reserves the right of a solicitor to advertise, but severely restricts personal injury advertising. The Act prohibits advertising, directly or indirectly, referring to claims, or possible outcome of claims, for damages for personal injury. Phrases such as 'motor', 'workplace' and 'public place' accidents are also prohibited in advertisements, along with phrases such as 'no win no fee', 'first consultation free', 'most cases settled out of court' and 'insurance cover arranged to cover legal costs'. Furthermore it prohibits advertising of any type in an 'inappropriate location', such as a hospital, doctor's surgery, funeral home or other location of similar character.

The 1996 and 2002 advertising regulations were mostly in response to government concerns on the effectiveness of the existing regulations due to the large number of cases brought by members of the Irish army on claims of hearing impairments, due to a lack of ear protection (the so-called army deafness claims). In addition, the belief of the government, supported by the Law Society, which was never in favour of advertising in the first place, was that 'ambulance chasing' was responsible for the increase in the volume of personal injury claims in general over the past 10 years and this brought the solicitor profession into disrepute. No independent evidence was used to support this argument, therefore the motivation behind the government's advertising reforms is not clear but it is possibly an attempt to reduce the government's exposure to litigation.

One concern with these advertising restrictions is that individuals will now find it more difficult to take (genuine) personal injury claims due to information restrictions on the availability of suitable solicitors. Therefore access to justice is likely to be impaired due to high consumer search costs. Indeed, the debate on legal services in Ireland has never explicitly mentioned access to justice issues and instead concentrated on purely competition reforms. In addition, these advertising restrictions are likely to have adverse effects on competition. Stigler's (1961) seminal article on the economics of information viewed informed consumers as a crucial ingredient for a competitive market. Empirical evidence on the effects of advertising in self-regulated professions tend to support this view with the majority of studies suggesting that advertising applies downward pressure on fees, with little if any adverse effects on quality (Love \& Stephen, 1996).

A recent OECD report on regulatory reform in Ireland called for further reforms 
in legal services especially in relation to increasing competition for conveyancing services by allowing banks and financial institutions to compete in this market and also called for continued freedom of advertising. In addition the OECD was in favour of moving control of education and entry away from the Law Society (OECD, 2001). It is yet to be seen whether the Irish government will bring forward regulations to address these issues, currently it is nowhere near the top of the government's agenda.

Irish regulatory reform captured. Of particular concern in the Irish case was the removal of proposals to increase competition in conveyancing. Increasing competition was seen, at the time, as a major step forward in dealing with the conveyancing monopoly. However this attempt at regulatory reform failed.

One reason for such failure is a perception that the regulation or regulators are 'captured' by private interest groups who lobby in order to achieve their own (private) interests. The Law Society is one such private group and therefore this sets up the question of whether the Law Society used its influence to achieve benefits for its members and by doing so achieve favourable regulatory changes. Shinnick (1998) investigated this capture issue in relation to the Solicitors (Amendment) Bill 1994.

An analysis of the debates that took place in Parliament and in the media suggested the Law Society had a crucial role to play in dropping this important proposed reform (Shinnick, 1998). Talking to the media following the publication of the Bill, the Director General of the Law Society was quoted as saying that "this Bill, in fact the vast majority of it, has been sought by the Law Society and is welcomed by the Law Society and is in fact very largely drafted by the Law Society". ${ }^{20}$ This is supported by the debate in Parliament where the Minister indicated that the Law Society did have a role in drafting the legislation. Furthermore the Minister, when justifying the decision to drop the competition reforms stated, "having regards to representations which I have received ... it may be that they are not the best way forward". ${ }^{21}$ Further evidence came from an analysis of the composition of Parliament at the time the Bill was debated. The most vocal opponents of the Bill had an association with the legal profession. In addition to the 166 members of Parliament, $16(10 \%)$ were members of the legal profession, while an additional $23(14 \%)$ were members of other professions, such as medicine, accountancy and auctioneering. Therefore $24 \%$ of members had a vested interest in defeating the most controversial section of this Bill. Also at the Committee Stage, where amendments to the Bill are agreed, five members $(31 \%)$ of that committee were solicitors.

The defeat of competition proposals in the conveyancing market alludes to the power of the Law Society in Ireland, a point that was acknowledged in the parliamentary debates when the Minister was accused of "surrendering to the lawyer's lobby" and when the 1994 Bill was referred to as "testimony to how well the legal lobby is functioning". ${ }^{22}$ This level of influence must be overcome if future reforms are to be successful. One possible benefit of the threat to end the solicitor's conveyancing monopoly was a so-called 'announcement' effect. That is, once attempts were made to introduce competition, solicitors may have already begun to reduce their conveyancing fees in the expectation of increased competition. It is not 
clear to what extent this occurred in Ireland, but there is a perception that fees have fallen since 1994. The announcement effect was quite strong in the UK where between 1984, when the introduction of licensed conveyancers was announced, and 1987, when they eventually entered the market, fees fell (Paterson et al., 1988).

Summary. The current situation in Ireland therefore is of a partially successful attempt to introduce regulatory reform, based around competition policy reforms without any explicit mention of either access to justice issues or overcoming the power of the legal profession. A crucial attempt to bring about competition in conveyancing services failed after the Law Society made representations and so the extent of regulatory reform in Ireland is based around rules on advertising. Initially law firms were allowed to advertise their services, then their fees, but subsequently more restrictions were added due to government fears that the public were being misled by certain forms of advertising. First, the 'no win no fee' rule was more clearly specified to indicate that if a client lost an action they may still be liable for costs, then this phrase was banned altogether. Second, 'ambulance chasing' behaviour could not be advertised and third, 'personal injury' advertising was severely restricted.

In Ireland we have therefore seen a failed attempt to move away from selfregulation to more market-based incentives by attempting to allow competition in conveyancing and by initially relaxing advertising restrictions, thereby attempting to achieve a good mix of self-regulation and market incentives. However, in more recent times this mix has dissolved by failing to introduce competition in conveyancing and by reverting to more restrictive advertising regulations. What we have therefore in Ireland is not only a failed attempt at regulatory reform but also a lost opportunity to achieve a mix of self-regulation and market-based incentives in the provision of legal services.

Barristers have escaped any reform whatsoever, despite concerns raised in the media over the very high level of fees earned by some barristers in the various public enquiries and tribunals that have occurred in Ireland over the last number of years. Despite the FTC criticism of the division of the profession into solicitors and barristers, this issue was never addressed in any legislation. Furthermore, a recent report on regulatory reform in Ireland (OCED, 2001) calling for further reform in Irish legal services has yet to be acted upon.

\section{The Netherlands}

Introduction-impetus for reform. In contrast to the common law countries of Australia and Ireland, a civil law country such as the Netherlands does not have a legal profession divided into barristers and solicitors, but it has advocates and notaries. ${ }^{23}$ Advocates deliver the services of both barristers and solicitors. Notaries are not only private consultants but also issue authorised certificates, which are required for many transactions, such as transfer of real estate, establishment of corporate personality, making wills and prenuptial agreements. It therefore acts in 
the interests of third parties and thus is a public service. The substantial revision in 1999 of the Notary Act 1842 was inspired by the ideals of regulatory reform.

The Advocatenwet (Law on Advocates) dates from 1952. From the very beginning it empowered the professional association (Nederlandse Orde van Advocaten, NOvA) to self regulate. NOvA has all the features of a profession, including compulsory membership of all practising advocates, which includes the acceptance of its jurisdiction. The self-made regulations provide for a three-year apprenticeship under supervision and external courses under the auspices of NOvA. Disciplinary bodies of colleagues chaired by judges decide on complaints submitted to them by the local dean, when mediation efforts fail. The more controversial selfmade regulations that are highly relevant in the context of regulatory reform will be discussed below.

Apart from more than 11,000 advocates there are 1,400 notaries and 2,100 legally qualified staff (i.e. candidate notaries). Until the 1999 revision of the Notary Act 1842, in return for the allegedly impartial public service, ${ }^{24}$ the number of notary offices was restricted and the tariffs for the various certificates were fixed. Notary offices and practices are modelled on advocates. The professional association of notaries (Koninklijke Notariële Beroepsorganisatie, KNB) gained self-regulatory powers in 1999.

The potential impact of regulatory reform is comparatively low in the advocate profession and comparatively high in the notary profession. This is based on the relative number of advocates per 100,000 inhabitants, which more than tripled between 1970 and 1995, from 15.9 to 51.6, while in the same time period the number of civil cases in court per 100,000 inhabitants doubled. As a consequence the focus of the average advocate's practice shifted from court representation and litigation to negotiation and consultancy outside court. Legal advice in the Netherlands is not part of the monopoly domain because of strong competition from the accounting and banking professions.

Regulatory reform with respect to compulsory court representation is less relevant to most advocates' practices and so had less impact than hoped for. The professional monopoly is an economic asset for divorce lawyers only 35,000 divorces per year). Conversely, the notaries derive $94 \%$ of their earnings from their professional monopoly and in particular conveyancing accounts for $70 \%$ of net turnover. ${ }^{25}$ In addition, the notaries lowered the tariffs for real property transactions in 1991, 1994, and 1996, thus implicitly acknowledging their monopoly rents. Their defence of these high tariffs, namely a cross subsidy for the non-profitable family practice was not very convincing in times of computerisation in office work. More fuel to the regulatory reform debate was added by a report ${ }^{26}$ which calculated that costs could be reduced by $14 \%$, thereby making a family practice profitable as well.

Regulatory reform, of which the legal profession was only one area, started in 1994 when a new government assumed office. The Minister of Economic Affairs Mr Hans Wijers, in particular, took the lead to reinforce market incentives at the expense of state regulation along three lines. First, the Competition Law 1997 established the Dutch Antitrust Agency (Nederlandse Mededingingsautoriteit). Whereas the old Competition Law only outlawed abuses of market dominance, thus 
Table 1. Representation up to $€ 5,000$

\begin{tabular}{lcc}
\hline Representation & Plaintiff (all cases) (\%) & Defendant (exclusive default cases) (\%) \\
\hline Advocate & 16 & 26 \\
Bailiff & 71 & 17 \\
Others & 12 & 7 \\
Self help & 1 & 50 \\
Total & 100 & 100 \\
& $(n=2,785)$ & $(n=959)$ \\
\hline
\end{tabular}

Source: Bruinsma (2002).

transforming the Netherlands into a cartel paradise, the antitrust agency is authorised to issue orders against market dominance itself. Second, public utilities and public services have been partly privatised. Third, and most relevant to the regulatory reform of the legal profession, specific branches and acts are scrutinised on their competition hampering function under the MDW project. ${ }^{27}$

Overview of reforms. A 1995 report (Domeinmonopolie Advocatuur) studied the monopoly domain of advocacy, where according to statutory law, only advocates are allowed to represent clients in district courts and higher. The report concluded that a fair trial is best guaranteed by compulsory representation. Two years later the Committee on the Reappraisal of Compulsory Representation $1997^{28}$ proposed to restrict the advocate's exclusive domain to money claims higher than $€ 5,000$, representing a doubling of the threshold. Money claims up to $€ 5,000$ could be filed at sub-district court level without compulsory representation. This recommendation was enacted in 1999. At first sight this seems a dramatic step but research has revealed that $82 \%$ of all money claims did not require representation under the old regime (Freudenthal, 1996). It remains to be seen whether the committee's second recommendation to raise the financial threshold gradually to $€ 10,000$ will be implemented.

Table 1 details the changes in representation up to $€ 5,000$. Only $1 \%$ of all plaintiffs sue without help and the advocate's legal monopoly has been substituted by an actual market dominance of bailiffs. ${ }^{29}$

The 1995 report also investigated the self-made representation regulations with respect to their potential protection of group interests and developed a framework for the assessment of the Dutch Bar Association regulations. Regulations that are in the general interest, such as the regulation on in-service training of apprentices are allowed, but regulations which were seen to be in the self-interest of the members of the Dutch Bar Association are criticised. A good example in this latter category was the regulation that employed lawyers could not be advocates as they were not independent vis-à-vis their employer. The report advised NOvA to remove this barrier. A new regulation came into being in $1997,{ }^{30}$ but contrary to the Bar's fearful expectations (an influx of 2,000 new advocates) it turned out that less than 300 corporate lawyers and other in-house counsel made use of this opportunity.

Interviews with 35 new advocates (Gunst \& De Groot-van Leeuwen, 1999) and 
a survey with 129 respondents (Gunst \& Bruinsma, 2002) made it clear that lawyer's personal motives drove this result. A follow-up survey among corporate lawyers who did not apply (173 respondents) supported the view that the compulsory three-year training period was prohibitive and the added value of a corporate lawyer as an advocate was questioned. The new regulation on employed advocates is still a bone of contention between NOvA and the insurance companies because their legal departments want to deal with their clients' cases from start to finish, whereas NOvA sticks to the principle that any client should have a free choice of advocate.

Reforms also came by lifting the ban on advertising in $1989^{31}$ and this reinforced an already established move towards specialisation with 20 specialised sections emerging within the Bar. About half of all advocates are members of one or more specialised sections. An advocate is only allowed to advertise their specialisation if they are a member of the respective section, which has its own requirements on compulsory courses and practice profile. A quality certificate is then issued which can help to tackle the asymmetry problem in a better way than just price information, because it introduces group control on quality.

Further reform came about by repealing the guideline on fee calculation. Until 1997 the Bar Association recommended billing on the basis of an hourly fee $(€ 136$ in 1996). Compared to all other consultants except notaries, the fee was generally regarded as much too high and prohibitive for small enterprises. However the hourly fee guideline was not binding and therefore not effective, so the Dutch Bar Association was quite willing to repeal it. In addition, as part of their original code of conduct, billing on the basis of no-win no-fee was banned, along with billing as a percentage of the awarded claim. However, in 2002 the new Antitrust Agency declared that this guideline amounted to a violation of competition law. The Bar Association, backed by the Ministry of Justice, responded by immediately elevating the guideline into a regulation. ${ }^{32}$ As in Ireland tort litigation, American style, is feared.

The Notary Act revised. Posner (1995) compares the traditional legal profession to a medieval guild. In the Dutch context the notaries resembled a medieval guild until the mid-1990s, the essential features being the statutory limit to the number of notaries and fixed tariffs for certificates. With the enactment of the Notary Act 1999, serious encroachments on both strongholds were made. With an eye on the absolute number of notaries, the professional association managed to function as a closed shop during a full century with 676 notaries in 1849 and just 818 in 1947. Pressure from within (a growing number of candidate notaries who saw their waiting period prolonged to more than 15 years) called on the KNB to increase the number of licensed notaries to 1,056 in 1994. As the number of candidate notaries had doubled in the same time period (620 in 1947 to 1,211 in 1994) it was just a drop in the ocean. Regulatory reform did the rest.

The outcome of the 1999 Act is partial liberalisation where candidate notaries who finished their six-year in-service training are still not allowed to open a notary office, unlike advocates who can do so after their three-year apprenticeship, until they submit a business plan to an expert committee in which the local notaries have a say. ${ }^{33}$ The notaries lost their battle for fixed tariffs as well. Their claims that price 
reductions would lead to deterioration in the quality of service, through an increase in the number of complaints and the number of indemnity claims, fell on barren ground. Instead, it was considered that quality could be maintained through high entry standards.

Summary. Three main reforms have taken place in the Netherlands: (i) restrictions on advocate's exclusive domain to money claims greater than $€ 5,000$, gradually increasing to $€ 10,000$; (ii) removal of ruling that employed lawyers could not be advocates; and (iii) removal of ban on advertising, reinforcing a tendency towards specialisation. We therefore see a move towards market-based incentives in the Dutch regulatory reform agenda, resulting in a mix of self regulation and marketbased incentives governing the legal profession. However, no explicit recognition of the social aspects of the professions has driven the regulatory reform agenda. Instead access to justice issues were meant to work via competition effects with cheaper (and therefore more) access through lower prices. Similarly reducing monopoly rents was how the power of the profession would be reduced.

At a stock taking conference on the MDW project in The Hague in June 1998 the overall conclusion was that while some major initiatives had taken place, most of them remained half hearted and lacked sufficient implementation to become effective. In addition, the privatisation of Dutch Railways and the chaos following the liberalisation of the taxi market reduced public support for the regulatory reform agenda. This was a set back because the Ministry of Economic Affairs (Mr Wijers), the prime mover of the project, considered that a reform agenda could only succeed if there was sufficient public support. In advance of the general election in May 1998, Mr Wijers announced he would not stay in office and as a consequence the programme on regulatory reform lost its driving force and with this its appeal. In the next general election held in May 2002, electoral support for the coalition parties dwindled from almost two thirds to slightly more than one third in Parliament and therefore regulatory reform is no longer an issue in Dutch politics.

This does not bode well for the regulatory reform process given that the OECD (1997) identifies strong and consistent support at the highest political level as one of the most important elements for successful regulatory reform so as to overcome vested interests in private and public sectors. On a more positive note, although the political impetus is no longer present, regulatory reform has its own momentum and has brought about some lasting effects in the legal profession. Further advancement of the regulatory reform agenda must place the public interest as the starting point for any regulatory reform policy and in this light consider the potential market failures that may occur with the introduction of market-based incentives. A successful regulatory reform agenda will crucially depend on the extent to which a mix of selfregulation and market-based incentives, coupled with recognition of the social aspects of professions, are successfully addressed.

\section{Comparative evaluation of regulatory reform in the legal profession}

In its crudest form the deregulation campaign pays little respect to legal professionalism. Two quotations taken from Posner will do to illustrate this extreme position: 
"Something like the evolution from guild production to mass production and the concomitant decline of artisanality, is occurring today in the market of legal services" (1995, p. 47), and: "I am inclined to favor the complete deregulation of legal services, except that courts should be allowed to establish and enforce criteria for the right to appear before them in an advocate's role because incompetent counsel impede and confuse the conduct of litigation to the prejudice of other litigants" (1999, pp. 281-282). In this view, legal services outside court work are nothing special (law should be treated as any other business) where monopoly rents are the problem and more market incentives are the solution.

However, such a campaign does not address sociological aspects of the legal profession. Efficiency is the hallmark of the market, but the market itself cannot accomplish social justice. In one way or another the state intervenes to overcome the failure of the legal profession in this regard. The access to justice issue asks for a broader perspective than an efficient market. A persistent problem with reforming the legal profession is that individual consumers of legal services are frequently 'oneshot' players (Galanter, 1975) who are disparate and diffuse and so do not form a coherent and persistent lobby group. In their zeal to demolish anti-competitive regulations, competition reformers are liable to forget about the need for the positive and protective regulation that is necessary to constitute a competitive market for the benefit of individual and less powerful consumers.

\section{Australia: access to justice impaired}

In only one area of service to individual clients is there evidence that competition reform in Australia had a significant effect on fees. This is in conveyancing services, the one area where lawyers' monopoly has, to some extent, been formally withdrawn. In 1992 the TPC found that conveyancing fees tended to be lower in jurisdictions where non-lawyers were allowed to compete with lawyers (TPC, 1992). In New South Wales after the relaxation of the Law Society's restrictions on advertising in 1992 it was clear that advertised fees for conveyancing were much lower than scale fees (TPC, 1992; Weisbrot, 1993).

A comparison of conveyancing fees between 1994 (when the Legal Profession Reform Act 1993 came into effect) and 1996 found that the mean professional fees charged by small law firms decreased in real terms by $17 \%$ due to increased competition. The abolition of the fee scales was a significant factor in this decrease. The most common method of setting fees before the reforms was the scale fees (based on property value), but by 1996 most firms had replaced this with a flat fee or a negotiated fee. Advertising was also important since firms that advertised charged lower fees than those that did not [see Baker (1996) for further details of these results]. ${ }^{34}$

However, in the area of litigation where legal professional costs most affect access to justice, all the reforms appear to have made no difference at all to the accessibility and affordability of legal services to ordinary individuals. Wright et al. (1998) conducted a comprehensive study of legal costs in motor vehicle accidents claims litigated in Sydney before and after reforms in the Legal Profession Act 1993. 
These reforms were expected to increase competition and decrease fees by repealing costs scales and by allowing advertising, no win-no fee costs agreements and modest success premiums. ${ }^{35}$ The study found no change in costs under the new conditions of supposed competition. The study also did not find any evidence that no-win nofee agreements increased people's willingness to make a claim. On the whole nowin no-fee agreements were simply replacing informal agreements that existed previously. There was no evidence that (i) the number of clients entering into nowin no-fee agreements has increased; and (ii) costs of litigation had decreased (Wright et al., 1998). Thus while advertising and other reforms may have had some impact on conveyancing, it appears to have had no impact on fees for litigation where legalistic adversarialism drives costs up.

By contrast, it seems clear that business consumers benefited more from reforms than individual consumers (Hanlon, 1997; Heinz et al., 1998). Along with the federal government's decision to pursue competition reform to the profession, corporate clients started requiring solicitors' firms to justify their bills and tender for work. Companies became much more willing to use different firms for different tasks, employ in-house counsel to do tasks at a fraction of the price external firms would have charged and to use accountants and business advisers instead of lawyers (Clifton-Steele, 1994; Parker, 1997b; Ross, 1997). While in theory the law preserved lawyers' monopoly over legal services, private solicitors were in fact competing with in-house counsel, accountants, management consultants and others in a deregulation of sorts. Not only had fees dropped dramatically but corporate clients had improved their control over the quality of legal services offered to them by demanding clearer billing practices, less wastage through over-servicing and more commercially oriented services (see, for example, Clifton-Steele, 1994). ${ }^{36}$ By March 1994 when the TPC's final report was released, the profession, or at least the large firm solicitors who controlled the profession, had largely accepted the need to be responsive to competition policy. ${ }^{37}$ Therefore a 'pure' competition-driven policy will inevitably tend to benefit those with greater market power and greater resources in society and will tend to have less of an effect on those with less power. One exception to such a tendency was the conveyancing market.

\section{Ireland: failure of regulatory reform}

As noted above, the Law Society has the capacity to act as a cartel through its use of recommended scale fees for conveyancing, its control over entry and conduct, and its restrictions on advertising. These factors can contribute to stifle competition and support high fees. A review of some Irish studies will examine these issues.

Shinnick (1998) conducted the first comprehensive studies of Irish solicitors and collected data on the numbers of firms, number of solicitors and location of firms, the conduct of solicitors in terms of their advertising behaviour and fees charged for hypothetical conveyancing services. Herfindahl indices ${ }^{38}$ were calculated to measure the degree of concentration in the market and indicated that if the market was defined broadly in terms of individual counties (where the Law Society have local branches), then these regions were not overly concentrated. However 
more recent evidence (Shinnick, 2002) indicated that if conveyancing markets are defined more locally (as is often the case with professional services) then concentration levels vary considerably, with high concentration in some regions. This, along with entry restrictions imposed by the Law Society, could be interpreted as a form of market failure.

In terms of solicitor advertising, solicitors were asked whether they advertise and in what form. Responses highlighted a high degree of variation, for example in seven of the 29 regions no form of media advertising took place. When asked why this was the case, solicitors indicated that there was an agreement by the local Law Society in some regions not to advertise in the media. On average only $7 \%$ of firms advertised in the media, ranging from 0 to $29 \%$. Only $13 \%$ advertised in the Golden Pages Telephone Directory, ranging from 0 to $38 \%$. This compares unfavourably with the extent of advertising in other countries. For example in England and Wales an average of $46 \%$ of firms advertised, in Scotland $56 \%$ advertised while in the United States $31 \%$ advertised (Love et al., 1992). The lack of advertising by Irish solicitors therefore compounds the information problem inherent in professional markets, due to a lack of information by consumers on the range of suppliers for a particular service and the prices charged for such a service.

Evidence of fee setting behaviour in Ireland indicated large price dispersions around the recommended scale fees for conveyancing. Solicitors were asked what conveyancing fees they would charge for three hypothetical house transactions. Price dispersions ranged from $31 \%$ to $47 \%$ below the mean to between $69 \%$ and $90 \%$ above the mean. On average the standard deviation was approximately $14 \%$ of the mean for each transaction. In addition there was some evidence to suggest that those firms who did advertise charged lower fees than firms who did not.

Other important issues concerned the effect of recommended fee scales on conveyancing charges and whether recommended fees can be considered similar to mandatory fees. Policy makers (see, for example, MMC, 1970; FTC, 1990) consider that there is little or no difference between recommended and mandatory fees, especially when rules governing firms conduct and discipline can be enforced. Shinnick and Stephen (2000), using data from both Ireland and Scotland, examined the effect such scales had on conveyancing fees by comparing fees charged by solicitors with the recommended scale fee for both countries. The evidence indicated that conditions do not exist for successful detection of deviations from a national cartel price but they do meet the conditions necessary for successful detection of deviations from local collusive arrangements. Evidence was found in both countries to show that discounting was practised.

For Ireland in particular, there seemed to be a greater degree of sensitivity to local market conditions and systematic deviations from the recommended scale. Local differences were not as significant in Scotland. However the authors point out that this does not necessarily mean that fees were determined competitively. Two possibilities exist: (i) local forces of supply and demand determine competitive fees; or (ii) local cartels determine fees. Furthermore it does not imply that the scale fee has no influence in determining fees. Evidence from Shinnick (1998) indicated that some solicitors used the lower of the two scale fees (i.e. the sale scale of $1 \%+£ 100$ 
rather than the purchase scale fee of $1.5 \%$ ) to determine fees in their local market. That is, the scale fees can be, and are, used as focal points in determining fees.

The Irish evidence indicates that more reform is needed given the structure of the solicitor market and the conduct of solicitors in terms of their advertising and fee-setting behaviour. In particular the lack of advertising by solicitors is disappointing given that advertising is seen as a means of keeping fees down. This is supported by the high variation in fees witnessed in the conveyancing market. More competition in the conveyancing market, through the introduction of non-solicitors, along with fewer restrictions on advertising would be desirable and may go some way towards improving access to justice.

\section{The Netherlands: a growing inequality}

Table 2 details the price developments for notary certificates in the Netherlands since liberalisation in 1999. More than 200 notary offices were randomly chosen and asked their fee for a notary certificate under different situations. In Table 2 the average price is indexed with 1999 as the base year.

Contrary to expectations and in conformity with the notaries' defence of fixed tariffs, prices went up after the liberalisation. In particular, fees for notary services in family law increased and the disparity in conveyancing fees grew, where the average fees in the lowest and the highest 5\% revealed large price differences. In addition, the market hasn't yet acquired the price transparency that fixed tariffs had. As the increase in notary offices lags behind the increase in the number of notaries, concentration in this market has increased. This is another factor that halts a downward trend in fees. It is expected that the market will do its restructuring work better in a less prosperous economy.

A similar development towards a growing inequality took place among the suppliers of legal services. Heinz and Laumann's (1994) metaphor of the two hemispheres applies here. At the commercial end of advocacy, mergers with notary offices and tax consultants prepared the way for lawyering on a European scale. Only the issues in national regulatory reform, such as the prevailing ban on

Table 2. Prices for notary certificates $(1999=100)$

\begin{tabular}{lccc}
\hline & 2000 & 2001 & 2002 \\
\hline Prenuptial agreement & 113 & 131 & 140 \\
Cohabitation contract & 111 & 119 & 127 \\
Last will & 140 & 154 & 169 \\
Conveyancing fee small piece of land & n.a. & 167 & 178 \\
Conveyancing fee for private home worth: & & & \\
$\quad$ (a) $€ 113,000$ & 96 & 105 & 119 \\
(b) $€ 245,000$ & 94 & 97 & 97 \\
(c) $€ 363,000$ & n.a. & 94 & 96 \\
(d) $€ 5,900,000$ & n.a. & 84 & 85 \\
\hline
\end{tabular}

Source: Eindrapport Commissie Monitoring Notariaat (1999-2003), Den Hague, 2003. [Final Report of the Committee Monitoring the Notary Profession, Table 3, p. 15]. 
cooperation between law and accounting firms and different ways of fee calculation, might be of interest to the corporate law firm. At the other end of the spectrum the access to justice movement, which materialised in the 1970s and 1980s in fully subsidised legal aid bureaus and social advocates who are completely dependent on legal aid certificates, was confronted with the new Act on Legal Aid 1994. In the height of the Dutch welfare state access to justice was the main concern, whereas since the early 1990s cost efficiency became at least as important. The revised Act on Legal Aid introduced a planning and control cycle, monitored by a new tier of financial supervisors. Research (Klijn, 2000) revealed that one out of four clients on legal aid before 1994 cannot afford (or is not willing) to bear the legal costs themselves under the new regime. Moreover, the number of social advocates remained restricted to about 800 die-hards against the background of an exponentially growing number of advocates. The income disparity ranges from $€ 30,000$ a year at the social end to $€ 300,000$ at the commercial end.

\section{Discussion}

While the competition agenda accomplished many important reforms in the legal profession, its achievements are patchy and weak. There is some support, particularly in Australia and the Netherlands, that the reforms benefited business clients more than private clients. This paper argues that the predominantly economic diagnosis of the failures of the legal profession led to a prescription for change that is insufficient to fully achieve reform. In addition such reform does not adequately address the other problems of access to justice and lack of consumer-friendliness in the legal profession that had been repeatedly identified and ignored before the competition reform agenda picked up steam. The social and ideological dimensions of the critique of legal professionalism calls for social and educational reforms to break down the domination of legal professional culture. This suggests the need for additional reforms that simply are not part of the current competition reform agenda.

Currently, regulatory reform centres on economic issues of self-regulatory regimes such as market structure and market conduct. While self-regulation has its critics, it nevertheless has certain efficiency aspects that centre on the asymmetric information problem inherent in professional services. For this reason self-regulation is a useful tool but it is not, and should not, be the only tool. Market-based incentives, when properly managed, can also provide benefits to consumers. There is therefore a need for two extensions to the economic focus in the regulatory reform agenda: (i) incorporate sociological issues; and (ii) provide additional protective regulation for consumers, especially private consumers who purchase legal services less frequently and are therefore open to abuse.

Sociological issues include the need to change the ideological power of legal professionalism and tackle the assumption that law is an area in which only a chosen few are allowed to be educated and practise. While it is important to have available legal and advocacy specialists, law should also become much more the domain of ordinary people so that dispute resolution, rights claims, government processes that ought to be a matter of simple everyday justice can be 'de-lawyerised', that is, reduce 


\section{EDWARD SHINNICK ET AL.}

the elitism but maintain quality. Citizens and members of other occupations (such as social workers, architects, engineers, etc.) ought to be skilled enough in the areas of law they are involved with, to not require a lawyer in straightforward situations. Just as corporations are using accountants, in-house managers with legal skills and others who are not legal specialists, should be able to use these skills as a natural part of their everyday participation in organisations (see Parker, 1999). This requires a deeper 'social' deregulation of legal professionalism that incorporates but also moves beyond economic competition policy.

The appropriate response to the legal profession's domination of a jurisdiction is social and educational campaigns that break down informal and ideological barriers, in addition to economic reforms that break down the formal barriers to competition. Competition policy can certainly help facilitate this deeper deregulation, not merely by relaxing or repealing legal restrictions on the way the legal profession currently operates the justice system, but also by debunking the mystique and remoteness the justice system is instilled with. However, competition reforms alone are incapable of constituting new ways of thinking about justice, about dispute resolution, about how lawyers' services should be used and how they can relate to other ways of doing justice such as ADR. True and lasting regulatory reform must incorporate both economic and social reform that incorporates a mix of selfregulation, state regulation and market-based incentives for optimal performance. This is a creative task for policy-makers, activists, potential clients, lawyers, incumbents of other occupations, theorists and others. The question is, are they up to this new task?

\section{Acknowledgements}

The authors would like to thank participants at the Fifth Biennial Meeting of the Working Group on the Comparative Study of Legal Professions, Peyresq, France, July 2000 and two anonymous referees for helpful comments.

\section{Notes}

[1] For a general discussion of professional regulation see Stigler (1971), Dingwall and Fenn (1987) and Posner (1974).

[2] The emerging term of 'co-regulation' is a useful way of describing such a mix.

[3] The term 'poldermodel' was coined recently for decision making on the basis of mutual trust and consensus building, referring to the joint efforts to transform water into land (Bruinsma, 2003).

[4] Welfare losses occur when consumers and/or producers fail to achieve all the possible benefits resulting from the production of goods and services.

[5] For a more detailed discussion on the sociology of professionalism see Parker (1999, Ch. 6).

[6] For example, the search and seizure powers of the Legal Services Commissioner in NSW, as discussed below.

[7] In Australia the six states and two territories each have separate regulatory arrangements for lawyers. Separate professional associations for barristers and solicitors exist in most states. In states where the two branches are fused there usually exists a bar association whose members voluntarily bind themselves to follow certain rules (see, for example, Ross, 2001).

[8] Legal Profession Regulations (NSW), Clause 20. 
[9] The Conveyancers Licensing Act 1992 (NSW), later called the Conveyancers Licensing Act 1995 (NSW).

[10] This issue was again under review in 2000-01, see NSW Law Reform Commission (2000).

[11] The amount paid to the legal practitioner cannot be calculated as a percentage of the amount recovered in proceedings. The practitioner can merely charge the normal fee plus a premium of up to $25 \%$ of the normal fee Legal Profession Act 1987 (NSW).

[12] For further analysis of the history of reform in New South Wales see Parker (1997a).

[13] Source: interviews by Australian author with members of the Victorian Attorney General's Department.

[14] The Legal Practice Board in Victoria, which is the official admitting body for lawyers, also accredits and oversees the rule-making and other regulatory functions of the recognised professional associations.

[15] In 1999, the government reiterated its plan to introduce licensed lay conveyancers (Lekakis, 1999).

[16] Competition Policy Reform Act 1995 (CW) and Competition Policy Reform (NSW) Act 1996 (and corresponding Acts in other states and territories).

[17] National Competition Review of the Legal Profession Act 1987.

[18] Legal Profession Amendment (Incorporated Legal Practices) Act 2000 (NSW).

[19] See Parker (2002) for further discussion of the failures of consumer and access to justice oriented reforms.

[20] Dail Eireann Parliamentary Debates, Vol. 440, No. 3, 10 March 1994: 602.

[21] Dail Eireann Parliamentary Debates, Vol. 440, No. 5, 23 March 1994: 1200.

[22] Dail Eireann Parliamentary Debates, Vol. 440, No. 3, 10 March 1994: 598-602.

[23] For a comprehensive overview of Dutch Law see Chorus et al. (1999) and Bruinsma (2003).

[24] Kocken (1997) questioned the impartiality of the notary services since the interests of third parties, especially the IRS, are easily overlooked. About $10 \%$ of notaries lost their independence when their offices integrated with large corporate law firms, a fact the professional association found difficult to defend.

[25] Kosten en opbrengsten van het notariaat (Costs and gains in the notarial business), KPMG, March 1994, The Netherlands.

[26] Ibid.

[27] Marktwerking, Deregulering \& Wetgevingskwaliteit (Market Performance, Deregulation \& Quality of Legislation).

[28] Commissie Herijking Verplichte Procesvertegenwoordiging, of which the Dutch author took part.

[29] Bailiffs in the Netherlands are allowed to combine a private business in debt collection and a public function of summoning a debtor in court and eventually executing a legal title. They make use of this comparative asset in publicity campaigns.

[30] Verordening op de praktijkuitoefening in dienstbetrekking 1997 (Ordinance Concerning the Law Practice as an Employee) replacing Verordening op de advocaat in dienstbetrekking 1977 (Ordinance Concerning the Employeed Attorney).

[31] Through Verordening op de publiciteit (Ordinance on Publicity).

[32] The regulation was called Verordening op de praktijkuitoefening (Ordinance on the Law Practice). Elevating the conduct guideline to a regulation was suggested by the Antitrust Agency which had declared the conduct guideline as a non legal guideline whereas a regulation has a legal status that had been checked to be in the general interest by the government.

[33] The purpose of such a plan is to check the viability and feasibility of a new notary office amidst the existing ones. This would incorporate aspects of public service inherent in notary offices (which differs from the exclusively private interests and the business orientation in law firms). This is partial liberalisation because notaries have a tool to prevent new entrants.

[34] When similar reforms were introduced in the UK, conveyancing fees also decreased (Domberger \& Sherr, 1989; Love et al., 1992; Paterson et al., 1988). However the Australian survey did not measure what effect competition by licensed conveyancers had, but the anecdotal evidence suggests that because conveyancers are not highly visible to consumers they are not widely used. The NSW Conveyancers Licensing Act 1992 is criticised for granting the Law Society regulatory control over their competitor conveyancers and for setting the standards too high for many conveyancers 


\section{EDWARD SHINNICK ET $A L$}

to become licensed. Additional reform to increase competition between lawyers and licensed conveyancers may further reduce fees.

[35] Costs scales only affected costs awarded against the loser of a court case. Between them, solicitors and clients could agree on a different basis for charging. In effect this made the costs scale a minimum fee.

[36] The author's interviews at the time suggested that fees for partners of mega-firms had dropped from approximately $\$ 500$ an hour to $\$ 250-300$ an hour (Parker, 1997b).

[37] This is not a uniquely Australian phenomenon. Research from other countries also suggests that the mega firms, with corporate business clients, is where competition for legal service is likely to be strong (e.g. Hanlon, 1997 on England) and that lawyers for individual clients do not take full advantage of opportunities for competition (Seron, 1996).

[38] These indices calculate market shares for each firm (see, for example, Stigler, 1968).

\section{References}

Аввотт, A. (1988) The System of Professions (Chicago, University of Chicago Press).

ABel, R. (1988) The Legal Profession in England and Wales (Oxford, Basil Blackwell).

Abel, R. (1989) American Lawyers (New York, Oxford University Press).

Baker, J. (1996) Conveyancing Fees in a Competitive Market (Sydney, Justice Research Centre, Law Foundation of NSW).

BRuinsma, F. (2003) Marktwerking in de taxibranche en de rechtshulpverlening, Nederlands furistenblad, $77,553-559$.

Bruinsma, F. (2003) Dutch Law in Action, Nijmegen Ars Aequi Libri (also at http://www.law.uu.nl/rt/ rsoc/bruinsma.asp).

Cerexhe, P. (2001) Leashing the Lawyers, Consuming Interest, 88, 26-28.

Chorus, J.M., Gever, P.H., Hondius, E.H. \& Koekkoek, A.K. (eds) (1999) Introduction to Dutch Law (The Hague, Kluwer).

Clifton-Steele, R. (1994) Peak Bodies Tell the TPC the Legal Profession is Already Most Competitive, Law Society fournal, March, 66-67.

Corones, S. (1996) Solicitors Subject to Trade Practices Act, Proctor, 16, 10-11.

Craven, G. (1995) Reforming the Legal Profession: Report of the Attorney-General's Working Party on the Legal Profession (Victoria, Department of Justice).

Dezalay, Y. \& Garth, B. (1996) Dealing in Virtue: International Commercial Arbitration and the Construction of a Transnational Legal Order (Chicago, University of Chicago Press).

Dietrich, M. \& Roberts, J. (1997) Beyond the Economics of Professionalism, in: J. Broadbent et al. (eds), The End of the Professions? The Restructuring of Professional Work (London, Routledge).

Dingwall, R. \& Fenn, P. (1987) A Respectable Profession? Sociological and Economic Perspective on the Regulation of Professional Services, International Review of Law and Economics, 7, 51-64.

Disney, J., Redmond, P., Basten, J. \& Ross, S. (1986) Lawyers (Sydney, Law Book Company).

Domberger, S. \& Sherr, A. (1989) The Impact of Competition on Pricing and Quality of Legal Services, International Review of Law E Economics, 9, 41-56.

Fair Trade Commission (1990) Report of Study into Restrictive Practices in the Legal Profession (Dublin, Government Stationary Office).

Fels, A. (1997) ACCC's View: Can the Professions Survive Under a National Competition Policy? (Canberra, Australian Government Publishing Service).

Fingleton, J. (1997) Standards of Competition in the Irish Economy, fournal of the Statistical and Social Inquiry Society of Ireland, 27, 87-109.

FREUdENTHAL, M. (1996) Incassoprocedures. Opzet voor een Nederlandse incassoprocedure met empirische en rechtsvergelijkende aantekeningen (Deventer, Kluwer).

Galanter, M. (1975) Why the 'Haves' Come Out Ahead: Speculation on the Limits of Legal Change, Law E Society Review, 9, 95-160.

Government of South Australia (1992) A White Paper: The Legal Profession (Government Offices, Victoria). 
Griffith, C. (2002) Road to Lawyer Reform Littered with Swindles, The Courier-Mail, 5 December.

Gunst, J.P. \& BRuInsma, F. (2002) Evaluatieonderzoek Verordening op de praktijkuitoefening in dienstbetrekking (Utrecht University).

Gunst, J.P. \& DE Groot-van Leeuwen, L.E. (1999) Motieven van de nieuwe toetreders. Over nieuwkomers, herintreders en weggelokte herintreders, Advocatenblad, februari, 157-159.

Halliday, T. (1987) Beyond Monopoly: Lawyers, State Crises, and Professional Empowerment (Chicago, University of Chicago Press).

Hanlon, G. (1997) A Profession in Transition? Lawyers, the Market and Significant Others, Modern Law Review, 60, 798-822.

Heinz, J. \& Laumann, E. (1994) Chicago Lawyers. The Social Structure of the Bar (Chicago, Northwestern University Press).

Heinz, J., Nelson, R., Laumann, E. \& Michelson, E. (1998) The Changing Character of Lawyers' Work: Chicago in 1975 and 1995, Law E Society Review, 32, 751-775.

Hilmer, F., Rayner, M. \& Taperell, G. (1993) National Competition Policy (The Hilmer Report) (Canberra, Australian Government Publishing Service).

Hulst, N. VAN (1996) De baten van het marktwerkingsbeleid, Economisch-Statistische Berichten, 10, 316-320.

Kagan, R.A. (1996) American Lawyers, Legal Culture, and Adversarial Legalism, in: L.M. Friedman \& H.N. Scheiber (eds), Legal Culture and the Legal Profession (Boulder, Westview Press).

KLIJN, A. (2000) Onafhankelijk bij de wetgever op schoot?, Recht der Werkelijkheid, 2000/2, 25-49.

Kocken, C.L.B. (1997) De hand van de notaris (Deventer, Kluwer).

LARson, M. (1977) The Rise of Professionalism (Berkeley, University of California Press).

Law Council of Australia (2001) Towards National Practice, Submission to the Standing Committee of Attorneys-General (Canberra, Law Council of Australia).

Law Reform Commission of Victoria (1991) Access to the Law: Accountability of the Legal Profession (Melbourne, Law Reform Commission of Victoria).

Law Reform Commission of Victoria (1992a) Access to the Law: Restrictions on Legal Practice: Report No. 47 (Melbourne, Law Reform Commission of Victoria).

Law Reform Commission of Victoria (1992b) Competition Law: Report No. 49 (Melbourne, Law Reform Commission of Victoria).

Legal Ombudsman (2002) Report on the Queensland Law Society and Baker Fohnson Lawyers, tabled in the Queensland Parliament by the Attorney General and Minister for Justice on Wednesday 4 December 2002. Available at http://www.justice.qld.gov.au/dept/pdfs/baker.pdf visited on 31 January 2003.

Lekakis, G. (1999) Outrage Over Law Change, Australian Financial Review, Friday 3 September, 31.

Love, J. \& Stephen, F. (1996) Advertising, Price and Quality in Self-Regulating Professions: A Survey, International Fournal of the Economics of Business, 3, 227-247.

Love, J., Stephen, F., Gillanders, D. \& Paterson, A. (1992) Spatial Aspects of Deregulation in the Market for Legal Services, Regional Studies, 26, 137-147.

Marshall, K. (2002) Long-awaited Reforms Revealed, Australian Financial Review, 19 April, 55.

Merritt, C. (2001a) Proposed System a Step Backwards: Hamond, Australian Financial Review, 30 November, 51.

Merritt, C. (2001b) Patmore Moving to Control Complaints, Australian Financial Review, 16 November, 49 .

Merritt, C. (2002) Williams Gets Tough on States, Australian Financial Review, 8 March, 51.

Monopolies and Mergers Commission (1970) A Report on the General Effect on the Public Interest of Certain Restrictive Practices so Far as they Prevail in Relation to the Supply of Professional Services (London, HMSO Cmnd 4463).

New South Wales Law Reform Commission (1979) The Legal Profession: Discussion Paper No. 1: General Regulation (Sydney, New South Wales Law Reform Commission).

New South Wales Law Reform Commission (1980) The Legal Profession: Background Paper III (Sydney, New South Wales Law Reform Commission).

New South Wales Law Reform Commission (1982) Second Report on the Legal Profession: Complaints, Discipline and Professional Standards (Sydney, Government Printer). 
New South Wales Law Reform Commission (1993) Scrutiny of the Legal Profession: Complaints Against Lawyers: Report 70 (Sydney, New South Wales Law Reform Commission).

New South Wales Law Reform Commission (2000) Complaints Against Lawyers: Review of Part 10: Issues Paper 18 (Sydney, New South Wales Law Reform Commission).

New South Wales Law Reform Commission (2001a) Report 99: Complaints Against Lawyers: An Interim Report (Sydney, New South Wales Law Reform Commission).

New South Wales Law Reform Commission (2001b) A Further Review of Complaints Against Lawyers: Issues Paper (Sydney, New South Wales Law Reform Commission).

OECD (1997) Report on Regulatory Reform (Paris, OECD).

OECD (2001) Regulatory Reform in Ireland (Paris, OCED).

Ogus, A.I. (1994) Regulation: Legal Form and Economic Theory (Oxford, Clarendon Press).

Olson, M. (1965) The Logic of Collective Action. Public Goods and the Theory of Groups (Cambridge, Harvard University Press).

O'Malley, P. (1983) Law, Capitalism and Democracy (Sydney, George, Allen \& Unwin).

Parker, C. (1997a) Justifying the New South Wales Legal Profession, Newcastle Law Review, 2, 1-29.

PARKer, C. (1997b) Converting the Lawyers: The Dynamics of Competition and Accountability Reform, The Australian and New Zealand Fournal of Sociology, 33, 39-55.

Parker, C. (1999) Fust Lawyers: Regulation and Access to fustice (Oxford, Oxford University Press).

Parker, C. (2002) Regulation of the Ethics of Australian Legal Practice: Autonomy and Responsiveness, University of New South Wales Law fournal, 25, 676-703.

Paterson, A. (1995) Legal Ethics: Its Nature and Place in the Curriculum, in: R. Cranston (ed.), Legal Ethics and Professional Responsibility (Oxford, Clarendon Press).

Paterson, A. (1996) Professionalism and the Legal Services Market, International fournal of the Legal Profession, 3, 137-168.

Paterson, A., Farmer, L., Stephen, F. \& Love, J. (1988) Competition and the Market for Legal Services, Fournal of Law E Society, 15, 361-373.

Posner, R. (1974) Theories of Economic Regulation, Bell fournal of Economics and Management Science, 5, 335-358.

Posner, R. (1995) Overcoming Law (Cambridge, Harvard University Press).

Posner, R. (1999) The Problematics of Moral and Legal Theory (Cambridge, Harvard University Press).

Priest, M. (2001) Law Society May Lose Power on Ethics, Australian Financial Review, 11 September, 50.

Restrictive Practices Commission (1982) Report of Enquiry into the Effects on Competition of the Restriction on Conveyancing and the Restriction on Advertising by Solicitors (Dublin, Government Stationery Office).

Ross, S. (1995) Ethics in Law: Lawyers' Responsibility and Accountability in Australia (Sydney, Butterworths).

Ross, S. (1997) Prospects for Structural and Economic Integration of the Australian Legal Profession, International fournal of the Legal Profession, 4, 267-289.

Ross, S. (2001) Ethics in Law: Lawyers' Responsibility and Accountability in Australia (Sydney, Butterworths).

Sallman, P. \& Wright, R. (2001) Legal Practice Act Review: Discussion Paper (Melbourne, Victorian Government, Department of Justice).

Seron, C. (1996) The Business of Practicing Law: The Work Lives of Solo and Small Firm Attorneys (Philadelphia, Temple University Press).

SHAmIR, R. (1995) Managing Legal Uncertainty: Elite Lawyers in the New Deal (Durham, Duke University Press).

Shaw, J. (1999) Incorporation of Legal Practices under the Corporations Law, Law Society fournal, November, 66-70.

SHINnICK, E. (1998) Competition, Regulation and the Determination of Fees in the Irish Conveyancing Market (Scotland, unpublished PhD Thesis, University of Strathclyde).

SHINNICK, E. (2002) Identifying Spatial Markets for Professional Legal Services, Regional Studies, 36, $147-155$.

Shinnick, E. \& Stephen, F. (2000) Professional Cartels and Scale Fees: Chiselling on the Celtic Fringe, International Review of Law and Economics, 20, 407-423. 
Solicitor (Advertising) Regulations, 1988 (Dublin, Government Stationary Office).

Solicitor (Advertising) Regulations, 1996 (Dublin, Government Stationary Office).

Solicitor (Advertising) Regulations, 2002 (Dublin, Government Stationary Office).

Solicitors (Amendment) Bill, 1994 (Dublin, Government Stationary Office).

Solicitors (Amendment) Act, 2002 (Dublin, Government Stationary Office).

SilveriI, J. (2003) 'Regulation one-stop shop' Law Institute fournal, September, 20-21.

Stigler, G. (1961) The Economics of Information, fournal of Political Economy, 69, 213-225.

STIGLER, G. (1968) The Organization of Industry (Illinois, Irwin).

Stigler, G. (1971) The Theory of Economic Regulation, Bell fournal of Economics and Management Science, 2, 3-21.

Towers, K. (2000) Ombudsman Raises Profession's Hackles, Australian Financial Review, 1 December, 44

Towers, K. (2001) Fresh Attack on Vic Ombudsman, Australian Financial Review, 2 February, 47.

Trade Practices Commission (1992) The Legal Profession, Conveyancing and the Trade Practices Act (Canberra, Trade Practices Commission).

Trade Practices Commission (1994) Study of the Professions: Legal: Final Report (Australia, Trade Practices Commission).

Wade, J. (1994) Discussion Paper: Reforming the Legal Profession: An Agenda for Change (Victoria, Attorney General's Department).

Weisbrot, D. (1990) Australian Lawyers (Melbourne, Longman Cheshire).

Weisbrot, D. (1993) Competition, Cooperation and Legal Change, Legal Education Review, 4, 1-27.

Wilson, J. (1980) The Politics of Regulation (New York, Basic Books).

Wright, T., Eyland, A. \& Cox, J. (1998) Claiming Under the Motor Accidents Scheme (Sydney, Justice Research Centre, Law Foundation of NSW).

Young, P. (1998) How High the Barriers? Australian Law fournal, 72, 746-747. 